\section{Multiple Supernumerary Teeth in a Nonsyndromic 12-Year-0ld Female Patient - A Case Report}

Thiago de Santana Santos ${ }^{1}$, Erick Ricardo Silva ${ }^{2}$, Ana Célia Faria ${ }^{3}$, Francisco

Veríssimo de Mello Filho ${ }^{3}$, Samuel Porfírio Xavier ${ }^{2}$
'Department of Oral and Maxillofacial Surgery and Periodontology, Ribeirão Preto School of Dentistry, USP - University of São Paulo, Ribeirão Preto, SP, Brazil ${ }^{2}$ Department of Oral and Maxillofacial Surgery and Periodontology, Integrated Center for the Study of Facial Deformities, Ribeirão Preto School of Dentistry, USP - University of São Paulo, Ribeirão Preto, SP, Brazil ${ }^{3}$ Department of Ophthalmology, Otorhinolaryngology and Head and Neck Surgery, Integrated Center for the Study of Facial Deformities, Ribeirão Preto Medical School, USP - University of São Paulo, Ribeirão Preto, SP, Brazil

Correspondence: Prof. Dr. Samuel Porfírio Xavier, Avenida do Café, S/N, 14040-904 Ribeirão Preto, SP, Brasil. Tel.: +55-16-36024109. e-mail: spx@forp.usp.br

Key Words: supernumerary teeth, hyperdontia, impacted teeth, radiographic images, surgical treatment.

\section{Introduction}

Supernumerary teeth (ST) are defined as excess teeth in the dental arch (1). According to a review article, the prevalence of ST in the general Caucasian population for the permanent dentition ranges from 0.1 to around $4 \%$, and ST seem to be more common in Mongoloid racial groups, with a frequency higher than $3 \%$ (2).

In general, ST are asymptomatic and are observed in full mouth periapical radiographs, in panoramic radiographs or in computed tomography scans $(3,4)$.

Few case reports of multiple ST not associated with complex syndromes have been published (5). The objective of the present case report is to describe a rare case of multiple ST in a nonsyndromic child and its surgical treatment, with a 3-year postoperative follow-up.

\section{Case Report}

A 12-year-old female patient attended the service of our School of Dentistry complaining of lack of eruption of the mandibular left first premolar. The patient had no complaint of pain, no signs of infection and was in good general health, with no other alterations. Intraoral clinical examination revealed vestibular bulging in the anterior region of the maxilla (Fig. 1). Panoramic radiographic examination revealed the presence of 14 ST associated with the four impacted third molars, the impacted first premolar and the maxillary right canine (Fig. 2A). Linear computed tomography was performed for a better localization of the ST in the anteroposterior direction (Fig. 2B).

Surgical treatment was performed under general anesthesia, with the extraction of all ST in a single surgical intervention. During the postoperative period, the patient did not complain of pain nor did she presented any signs or symptoms of infection. During the late follow-up period, due to difficulty in traction of the right upper canine and lower first premolar towards the dental arch, it was necessary to extract these teeth under local anesthesia (Fig. 3A). Radiographic examination 3 years after surgery revealed the absence of ST and diseases related to these teeth (Fig. 3B).

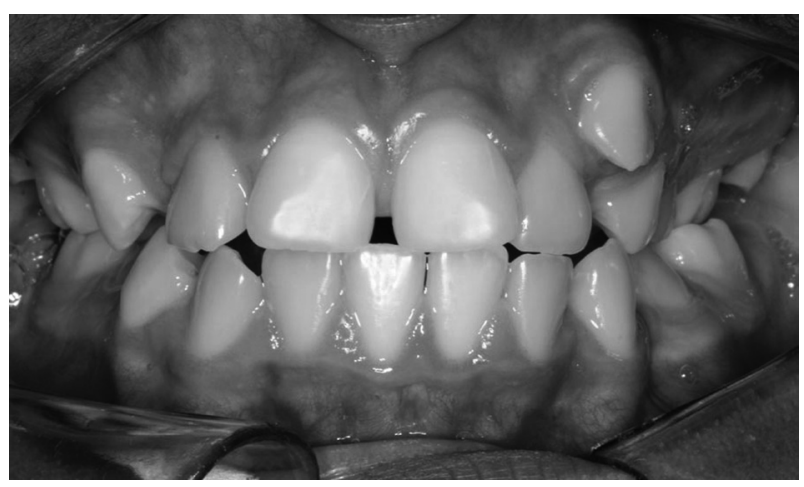

Figure 1. Initial intraoral clinical aspect of the patient. 


\section{Discussion}

Hyperdontia is an odontostomatologic anomaly characterized by an excess in tooth number, both erupted and unerupted. It can be described as "real" if determined by an increased number of teeth, otherwise it is "false" if caused by a delay in shedding of primary teeth beyond the transition period (6).

The presence of 14 impacted ST is very rare, with a reported prevalence of 0.2 to $0.8 \%$ in deciduous dentition and of 0.5 to $5.3 \%$ in permanent dentition on account of geographic variations $(5,7,8)$. In addition, the occurrence of multiple ST is less common than the occurrence of a single ST and is even more rare in the absence of a systemic condition or syndrome, such as cleidocranial dysplasia, Gardner syndrome or Down syndrome $(2,9)$. The literature shows that 76 to $86 \%$ of nonsyndromic cases involve only one supernumerary tooth and that 12 to $23 \%$ of cases present two ST $(2,10,11)$. Analysis of ST cases shows that the variation is small, with the presence of one or two ST being more frequent. A single ST occurs in 72 to $77 \%$ of cases, two occur in 18 to $27 \%$, and three in only 1 to $5 \%(2,12)$. The incidence of ST is generally higher in men, affecting premolars in approximately 10\% of cases and almost 75\% of these cases occur in the mandible $(4,13)$. Only $1 \%$ of nonsyndromic cases present multiple ST, which occur more frequently in the area of the mandibular premolars and in the anterior region $(5,10,13,14)$.

In the patient reported herein, ST were not related to syndromes nor associated with any systemic condition. Panoramic radiographs requested for the two sisters and the parents of the patient showed absence of ST. The etiology of this alteration is still unknown (15). Many hypotheses have been proposed to explain the development of these teeth, including atavism, tooth germ dichotomy, hyperactivity of the dental lamina, and genetic and environmental factors (10). The hereditary factor is believed to be important for
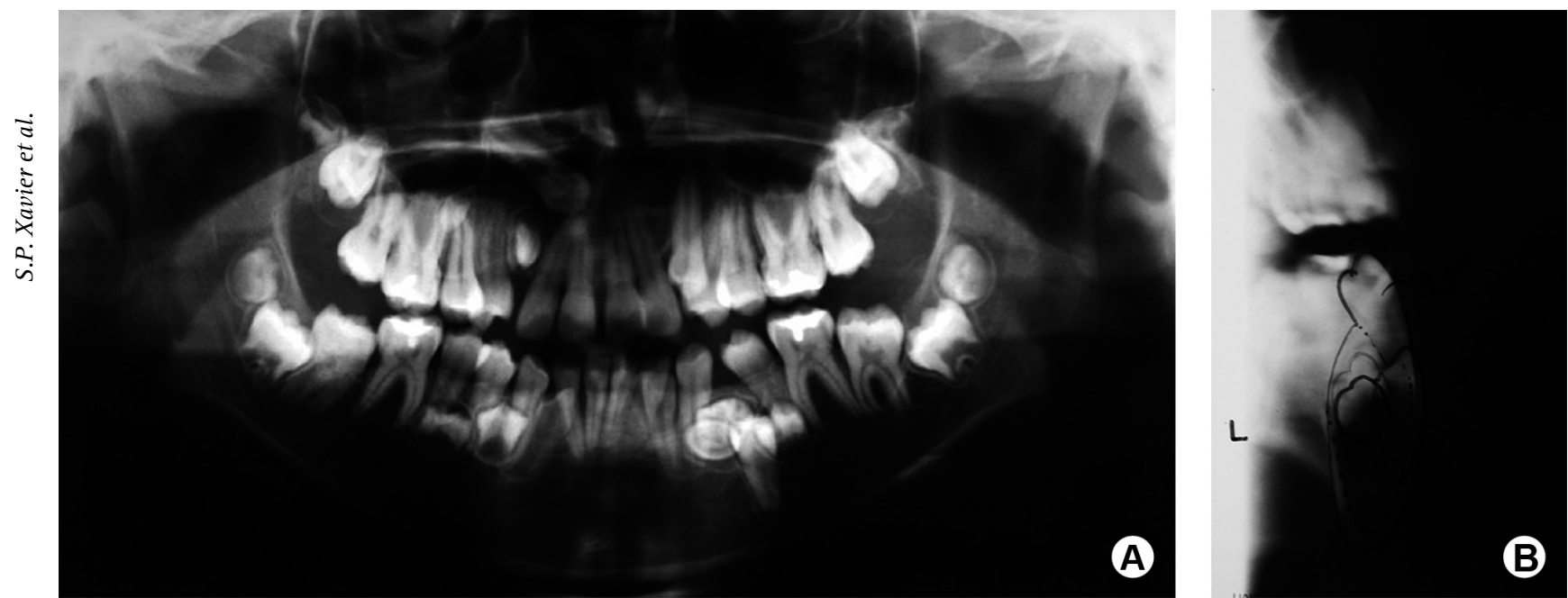

Figure 2. A: Panoramic radiograph showing the presence of supernumerary teeth. B: Linear CT scan showing the localization of supernumerary teeth in the region of the second lower left premolar. The image of the teeth was labeled for better visualization.
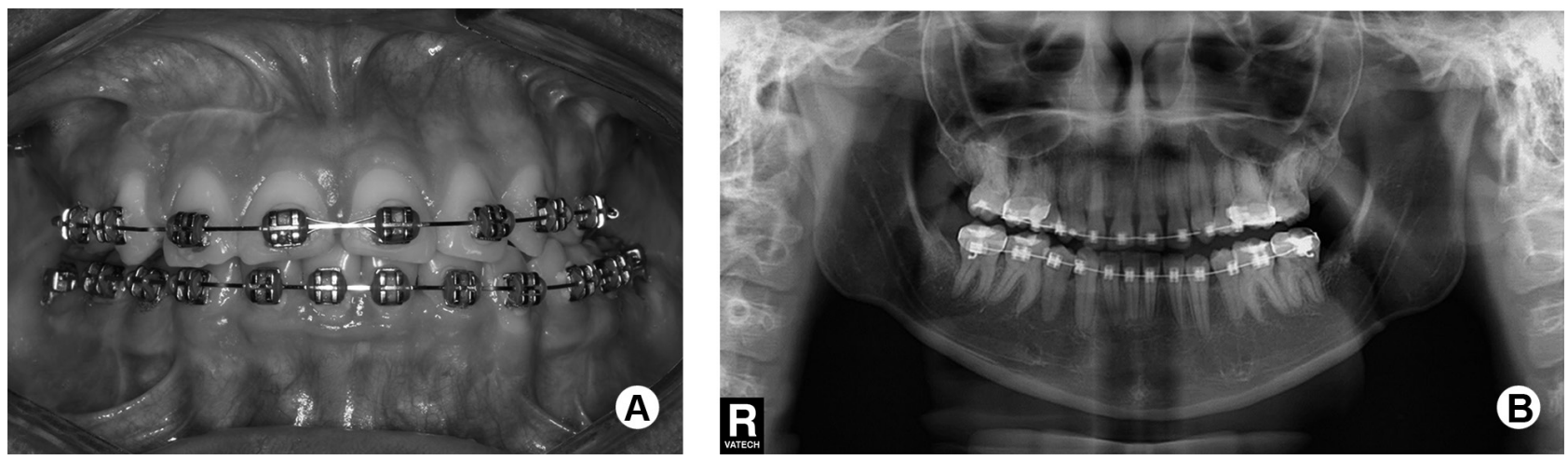

Figure 3. Postoperative clinical aspect 3 years after surgery showing better dental alignment and occlusion during the final phase of orthodontic treatment (A); Final radiographic aspect 3 years after surgery (B). 
the development of ST. There may be transmission of a recessive or dominant autosomal trait with incomplete penetrance, or the condition may be associated with an $\mathrm{X}$ chromosome (14).

Some ST are only impacted in the maxillary bones with no harmful effect and are usually identified accidentally during radiographic exams performed for other reasons (46). However, in some cases they may cause complications, including retention or delayed eruption of some permanent teeth, diastemas, dislocation, dental rotation, root resorption, periodontal lesions, pulp necrosis of adjacent teeth, and formation of a dentigerous (odontogenic) cyst $(7,10,16)$. Thus, an early diagnosis and appropriate treatment are essential for a successful solution (2).

The ability to properly evaluate ST to determine their relation with adjacent teeth and other anatomical structures is important for the decision about treatment, especially when extractions or ortho-surgical interventions are indicated. To reduce the chances of injury to the adjacent teeth and trauma to the surrounding tissues it is important to determine the best surgical access. Cone beam computed tomography is an important tool for the exact localization of impacted teeth, especially because it permits 3D reconstruction $(17,18)$. However, traditional periapical, occlusal and panoramic radiographs are of value for the correct planning of surgery (4). In the present report, imaging studies consisted of a panoramic radiograph and linear tomography, which allowed the correct localization of these teeth and consequently the best surgical access, in agreement with previous reports (19).

Contrasting the conduct of other authors $(6,20-22)$, who opted to leave the ST in situ due to the absence of any signs or symptoms that indicated their extraction, the prophylactic removal of all ST was performed in the present case to prevent potential complications, such as major occlusal alterations or tooth-related diseases, caused by the permanence of the teeth. Finally, in the present case, surgical intervention did not show complications, probably due to careful tissue manipulation and correct application of the mechanical principles involved in tooth extraction, which permitted a successful trans- and postoperative evolution of the patient. In addition, clinical and radiographic follow-up of the patient is of utmost importance since it has been demonstrated recurrence of ST, especially premolars, after surgical removal (23). A possible mechanism underlying this recurrence is that ST crypts were present but were not detected in the original radiographs (1).

The rare case presented here demonstrated that the early intervention combining extraction of the ST and orthodontic treatment could provide a satisfactory occlusion free of complications instead of maintaining the teeth in situ, which can be unpredictable.

\section{Resumo}

Os dentes supranumerários (DS) são alterações de desenvolvimento pouco frequentes, que podem aparecer em qualquer das arcadas dentárias e estão frequentemente associadas a sindromes como a displasia cleidocraniana e síndrome de Gardner. Múltiplos DS em indivíduos com nenhuma outra doença ou síndrome são muito raros. Diante dessa situação, o correto diagnóstico, tratamento e avaliação dos DS com estudo de imagens apropriadas são de significativa importância. No presente relato de caso, os autores apresentam imagens radiográficas de uma paciente não sindrômica de 12 anos de idade, gênero feminino, com 14 dentes supranumerários, em que o tratamento cirúrgico foi instituido sob anestesia geral, com extração de todos os DS em uma única intervenção cirúrgica. Durante o período pós-operatório, a paciente não se queixou de dor, como também não houve quaisquer sinais ou sintomas de infecção. Durante o acompanhamento, devido à dificuldade de tração do canino superior direito e primeiro pré-molar inferior em direção ao arco dental, foi necessário remover estes dentes sob anestesia local. 0 exame radiográfico de 3 anos após a cirurgia revelou a ausência dos DS e de doenças relacionadas com a existência desses dentes.

\section{References}

1. Mali S, Karjodkar FR, Sontakke S, Sansare K. Supernumerary teeth in non-syndromic patients. Imaging Sci Dent 2012;42:41-45.

2. Rajab LD, Hamdan MA. Supernumerary teeth: review of the literature and a survey of 152 cases. Int J Paediatr Dent 2002;12:244-254.

3. Klein OD, Oberoi $S$, Huysseune $A$, Hovorakova M, Peterka M, Peterkova R. Developmental disorders of the dentition: An update. Am J Med Genet C Semin Med Genet 2013;163:318-332.

4. Kawashita Y, Saito T. Nonsyndromic multiple mandibular supernumerary premolars: a case report. J Dent Child 2010;77:99-101.

5. Fardi A, Kondylidou-Sidira A, Bachour Z, Parisis N, Tsirlis A. Incidence of impacted and supernumerary teeth - a radiographic study in a North Greek population. Med Oral Patol Oral Cir Bucal 2011;16:E56-E61.

6. Inchingolo $F$, Tatullo $M$, Abenavoli FM, Marrelli M, Inchingolo AD, Gentile $M$, et al.. Non-syndromic multiple supernumerary teeth in a family unit with a normal karyotype: case report. Int J Med Sci 2010;7:378-384.

7. Ferres-Prado E, Prats-Armengol J, Ferres-Amat E. A descriptive study of 113 unerupted supernumerary teeth in 79 pediatric patients in Barcelona. Med Oral Patol Oral Cir Bucal 2009;14:E146-E152.

8. Yague-Garcia J, Berini-Aytes L, Gay-Escoda C. Multiple supernumerary teeth not associated with complex syndromes: A retrospective study. Med Oral Patol Oral Cir Bucal 2009;14:E331-E336.

9. Moraes MEL, Moraes LC, Dotto GN, Dotto PP, Santos LRA. Dental anomalies in patients with Down syndrome. Braz Dent J 2007; 18:346350.

10. Diaz A, Orozco J, Fonseca M. Multiple hyperodontia: report of a case with 17 supernumerary teeth with non syndromic association. Med Oral Patol Oral Cir Bucal 2009;14:E229-E231.

11. Fernandez Montenegro P, Valmaseda Castellon E, Berini Aytes L, Gay Escoda C. Retrospective study of 145 supernumerary teeth. Med Oral Patol Oral Cir Bucal 2006;11:E339-E344.

12. Liu DG, Zhang WL, Zhang ZY, Wu YT, Ma XC. Three-dimensional evaluations of supernumerary teeth using cone-beam computed tomography for 487 cases. Oral Surg Oral Med Oral Pathol Oral Radiol Endod 2007;103:403-411.

13. Hyun HK, Lee SJ, Ahn BD, Lee ZH, Heo MS, Seo BM, et al.. Nonsyndromic multiple mandibular supernumerary premolars. J Oral Maxillofac Surg 2008;66:1366-1369.

14. Batra P, Duggal R, Parkash H. Non-syndromic multiple supernumerary teeth transmitted as an autosomal dominant trait. J Oral Pathol Med 2005;34:621-625.

15. Wang XP, Fan J. Molecular genetics of supernumerary tooth formation. Genesis 2011;49:261-277. 
16. Hyun HK, Lee SJ, Lee SH, Hahn SH, Kim JW. Clinical characteristics and complications associated with mesiodentes. J Oral Maxillofac Surg 2009;67:2639-2643.

17. Brauer HU. Case report: non-syndromic multiple supernumerary teeth localized by cone beam computed tomography. Eur Arch Paediatr Dent 2010;11:41-43.

18. Wang WM, Wang $X$, Wang TM. Evaluation of nonsyndromic multiple supernumerary teeth using three-dimensional computerized tomography: a case report and literature review. J Contemp Dent Pract 2010;11:081-087.

19. Frederiksen NL. Diagnostic imaging in dental implantology. Oral Surg Oral Med Oral Pathol Oral Radiol Endod 1995;80:540-554.

20. Gunduz K, Muglali M. Non-syndrome multiple supernumerary teeth: A case report. J Contemp Dent Pract 2007:8:81-87.

21. Orhan Al, Ozer L, Orhan K. Familial occurrence of nonsyndromal multiple supernumerary teeth. A rare condition. Angle Orthod 2006;76:891-897.

22. Nagaveni NB, Umashankara KV, Sreedevi, S, Reddy BP, Radhika NB, Satisha TS. Multi-lobed mesiodens with a palatal talon cusp: a rare case report. Braz Dent J 2010;21:375-378.

23. Stevenson $W$, McKechnie AD. Recurring supernumerary teeth. Report of a case. Oral Surg Oral Med Oral Pathol 1975;40:76-80.

Received September 13, 2013 Accepted November 16, 2013 